\title{
Toward the Phenomenology of Aesthetic Instinct Developed through a Dialogue with F. Schiller $(1759-1805)^{*}$
}

Lee, Nam-In

(Seoul National University Department of Philosophy)

In On the Aesthetic Education of Man in a Series of Letters ${ }^{1)}$, Schiller introduces the concept of "the play-drive" (der Spieltrieb) as a central con-

* This paper was presented at the conference on "Logos and Aisthesis: Phenomenology and the Arts" that took place on July 30-August 1, 2012 at the Chinese University of Hong Kong. I thank Professor Lau Kwok-ying for his kind invitation to the conference. It was also presented on October 25, 2012 at the Colloquium of the Department of Aesthetics of Seoul National University. I thank Professor Oh, Chong-Hwan and Professor Shin, Hye-Kyoung for their kind invitation to the Colloquium. It was also presented on December 28, 2012 at the Colloquium of Philosophy Department of Fudan University. I thank Professor Sun Xiangchen for his kind invitation to the Colloquinum. This work was supported by the Korea Research Foundation Grant funded by the Korean Government(MEST) (NRF-2007-361-AL0016).

1) F. Schiller, On the Aestbtetic Education of Man in a Series of Letter, English and German Facing, trans. by E. M. Wilkinson and L. A. Willoughby, New York: Oxford University Press, 1982. In this paper, this work will be referred to with the abbreviation: the Aesthetic Education.

주제어: 쉴러, 예술본능, 유희본능, 현상학, 현상학적 환원, 미적 태도, 미적 감정, 미 적 관심, 미적 세계

Schiller, aesthetic instinct, play-instinct, phenomenology, phenomenological reduction,attitude, aesthetic feeling, aesthetic world 
cept of his aesthetics. The concept of the play-drive is the very foundation of the whole system of aesthetics developed in that work. In this paper, I will call Schiller's play-drive the aesthetic instinct ${ }^{2}$. In my view, Schiller's concept of the aesthetic instinct in the Aesthetic Education has two features. On the one hand, it could be developed into a fundamental concept of aesthetics that could shed a new light on various important aesthetic topics. On the other hand, it has its own difficulties that should be overcome before it can become a trulyfundamental concept of aesthetics.

It is the aim of this paper to clarify the phenomenological concept of the aesthetic instinct and to sketch the phenomenology of aesthetic instinct that has its basis on concrete aesthetic experience. In section 1, I will delineate Schiller's concept of the aesthetic instinct introduced in the Aesthetic Education. In section 2, I will assess Schiller's concept of the aesthetic instinct and in section 3, I will give a brief sketch of the phenomenological concept of the aesthetic instinct.

\section{Schiller's concept of the aesthetic instinct}

Schiller considers the aesthetic instinct to be the origin of art. Art is the result of the working of the aesthetic instinct, an instinct that is competent to cope with the total crisis of the mankind as a whole experienced at that time. In order to clarify the structure of the aesthetic instinct, Schiller makes a distinction between "Beauty as Idea" and "beauty in experience"

2) I will translate "Trieb" into "instinct". 
(the Aesthetic Education, 111) and considers "Beauty as Idea" to be the only legitimate concept of beauty. In this case, "Beauty as Idea" is the "pure rational concept of Beauty" (the Aesthetic Education, 69) by means of which "we are to decide whether that which in experience we call beautiful is justly entitled to the name." (the Aesthetic Education, 69)

How can we discover "Beauty as Idea" or the "pure rational concept of Beauty"? What is the method for discovering this concept? It cannot be ascertained from observation of experience, since it is "a concept of beauty derived from a source other than experience" (the Aesthetic Education, 69). According to Schiller, it has "to be discovered by a process of abstraction, and deduced from the sheer potentialities of our sensuo-rational nature" (the Aesthetic Education, 69). The method of abstraction is simply the method of discovering the "pure rational concept of Beauty". Employing the method of abstraction, "we must lift our thoughts to the pure concept of human nature; and since experience never shows us human nature as such, but only individual human beings in individual situations, we must endeavor to discover from all these individual and changing manifestations that which is absolute and unchanging, and, by the rejection of all contingent limitations, apprehend the necessary conditions of their existence." (the Aesthetic Education, 71). Schiller designates the method of abstraction "the transcendental way" (the Aesthetic Education, 71) that "will lead us out of the familiar circle of phenomenal existence, away from the living presence of things, and cause us to tarry for while upon the barren and naked land of abstractions." (the Aesthetic Education, 71) 
If we carry out this abstraction to the highest level with respect to the human being, we arrive at "two ultimate concepts" (the Aesthetic Education, 73) as the essential components of man. One of the "two ultimate concepts" in man is "something that endures" and the other of them is "something that constantly changes" (the Aesthetic Education, 73). "That which endures" in man is "his Person" (Person) and "that which changes" is "his Condition" (Zustand) (the Aesthetic Education, 73). The Person and the Condition are two principles that constitute human being. At this point, it is important to pay attention to the fact that they are two principles that conflict with each other endlessly. "The Person, which manifests itself in the eternally persisting ' $I$ ', and only in this, cannot become, cannot have a beginning in time" (the Aesthetic Education, 75), whereas "every Condition, $[\cdots]$ every determinate existence, has its origins in time" (the Aesthetic Education, 75). In Eleventh Letter, Schiller calls the Condition in man "the material", "the matter", "the formless content", "the sensuous", "the world" or "the reality", whereas he calls the Person in man "the law" (das Gesetz), "the disposition to the divine" (die Anlage zu der Gottheit) or "the form".

Since man is composed of two different principles in his real life, man is confronted with two contrary tasks. On the one hand, man is faced with the task of being faithful to his Condition. This task "insists upon absolute reality: he is to turn everything which is mere form into world, and make all his potentialities fully manifest." (the Aesthetic Education, 77) On the other hand, man is faced with the task of being faithful to his Person. This task "insists upon absolute formality: he is to destroy everything in him- 
self which is mere world, and bring harmony into all his changes." (the Aesthetic Education, 77)

Man is unable to fulfill these two tasks, if he does not have "two opposing forces which, since they drive us to the realization of their object, may aptly be termed instincts" (the Aesthetic Education, 79)3). One of the two instincts that Schiller introduces as one of the central concepts of his aesthetics is the sensuous instinct that "proceeds from the physical existence of man, or his sensuous nature." (the Aesthetic Education, 79) "Its business is to set him within the limits of time, and to turn him into matter" and "by matter in this context we understand nothing more than change, or reality which occupies time." (the Aesthetic Education, 79) The other instinct is "the formal instinct" that "proceeds from the absolute existence of man, or from his rational nature, and is intent on giving him the freedom to bring harmony into the diversity of his manifestations, and to affirm his Person among all his changes of Condition." (the Aesthetic Education, 81)

Schiller considers the sensuous instinct and the formal instinct to be the two fundamental instincts of man. It is "these two instincts which $[\cdots]$ exhaust our concept of humanity" and there is not "a third fundamental instinct which might possibly reconcile the two" (the Aesthetic Education, 85). The non-existence of "a third fundamental instinct", however, does not imply that there is no other instinct in man than these two. If there is no other instinct in man except them, "the unity of human nature"

3) E. M. Wilkinson and L. A. Willoughby translate "Trieb" into drive, but I translate it into "instinct". 
would be utterly destroyed by the "primary and radical opposition" (the Aesthetic Education, 85) of these two fundamental instincts.

Thus, there must be a third instinct that is supposed to restore "the unity of human nature" and it is none other than "the play-drive" or "the play-instinct" (Spieltrieb), the central concept of the Aesthetic Education. The play-instinct is the genetic product of the "reciprocal action" (the Aesthetic Education, 95) between the sensuous instinct and the formal instinct. Originally, these two instincts do not act reciprocally, since by their own natures, they are not in need of contact. "The sensuous instinct does indeed demand change; but it does not demand the extension of this to the Person and its domain, does not demand a change of principles. The formal instinct insists on unity and persistence - but it does not require the Condition to be stabilized as well as the Person does not require identity of sensation. The two are, therefore, not by nature opposed $[\cdots]$." (the Aesthetic Education, 85) But if we take a look at their operation in concrete situations, we cannot deny "that their tendencies do indeed conflict with each other" (the Aesthetic Education, 85). What is then the reason that they conflict with each other? It is "through a wanton transgression of Nature, through mistaking their nature and function, and confusing their spheres of operation" (the Aesthetic Education, 85) that they conflict with each other.

"A wanton transgression of Nature" implies that each of the fundamental instincts attempts to extend their power beyond its own sphere and thereby transgresses the sphere of the other fundamental instinct. Thus, the sensuous instinct attempts to go beyond its own sphere and transgresses 
the sphere of the formal instinct and, in a similar manner, the formal instinct attempts to go beyond its own sphere and thereby transgresses the sphere of the sensuous instinct. What happens then, if there is a transgression of this kind? According to Schiller, there arises "a new instinct which, precisely because the other two instincts co-operate within it, would be opposed to each of them considered separately and could justifiably count as a new instinct." (the Aesthetic Education, 97) As indicated earlier, Schiller calls this new instinct "the play-instinct" and seeks to clarify its identity and its relationship to the other instincts as follows:

"The sense instinct demands that there shall be change and that time shall have a content; the form-instinct demands that time shall be annulled and that there shall be no change. That instinct, therefore, in which both the others work in concert $[\cdots]$, the play-instinct would be directed towards annulling time within time, reconciling becoming with absolute being and change with identity." (the Aesthetic Education, 97)

Every kind of instinct has its own object to which it is directed. What is then the object of the play-instinct? Since the play-instinct is the result of the reciprocal action of the sensuous instinct and the form instinct, we could clarify its object by comparing it with the object of the sensuous instinct and that of the form instinct. "The object of sense-instinct, expressed in a general concept, we call life, in the widest sense of this term: a concept designating all material being and all that is immediately present to the senses. The object of the form-instinct, expressed in a general concept, we call form, both in the figurative and in the literal sense of this 
word: a concept which includes all the formal qualities of things and all the relations of these to our thinking faculties. The object of the play-instinct, represented in a general schema, may therefore be called living form (lebende Gestalt): a concept serving to designate all the aesthetic qualities of phenomena and, in a word, what in the widest sense of the term we call beauty." (the Aesthetic Education, 101) With respect to the object of the play-instinct, Schiller claims that beauty is "the object common to both instincts, that is to say, the object of the play-instinct" (the Aesthetic Education, 103).

Thus, the object of the play-instinct is beauty defined by Schiller as "living form" (lebende Gestalt). Since the object of the play-instinct is this beauty, it could properly be called the aesthetic instinct. In fact, in Twenty Seventh Letter, Schiller determines the play-instinct as "the aesthetic play-instinct" (der ästhetische Spieltrieb) (the Aesthetic Education, 211) or "the aesthetic instinct to form" (der ästhetische Bildungstrieb) (the Aesthetic Education, 215).

Thus, for Schiller, the play-instinct is just another name for the aesthetic instinct. The aesthetic instinct is called the play-instinct for the following three reasons. First, it is called play-instinct, since it is the result of the reciprocal action between the sensuous instinct and the formal instinct as a play between them, as discussed above. Second, it is called play-instinct, since it is simply the impulse or the force that drives man to play with beauty through the pronouncement that "with beauty man shall only play, and it is with beauty only that he shall play." (the Aesthetic Education, 
107) Third, it is called play-instinct, since it is directed to beauty or living form as the result of the play of life and form.

The play-instinct as the aesthetic instinct is the basic concept from which the other important concepts of Schiller's aesthetics such as beauty, aesthetic freedom, the aesthetic mood, the aesthetic feeling, play, appearance (der Schein), the aesthetic state etc. could be deduced. Let us take a look at the connection between the play-instinct and some of the other concepts of Schiller's aesthetics.

As discussed above, beauty as the object of the play-instinct is defined as living form, since it is the product of the reciprocal action of the sensuous instinct that has life as its object and the formal instinct that has the form as its object. After defining the concept of beauty, Schiller introduces two distinctions between two concepts of beauty.

The first one is the distinction mentioned above between "Beauty as Idea and beauty in experience" (the Aesthetic Education, 111). In this respect, it should be noted that the play-instinct as the result of the reciprocal action between the sensuous instinct and the formal instinct could have different modes of operation. In an ideal case, it could operate in the way that the sensuous instinct and the formal instinct as its two components could act with perfect balance and harmony. Except this ideal case, there are endlessly many cases in which the two instincts do act reciprocally in an unbalanced and unharmonious manner. For instance, the sensuous instinct sometimes could take precedence over the formal instinct, 
and vice-versa. Furthermore, in an ideal case, the play-instinct has "Beauty as Idea" as its object, whereas in the other cases, it has "the beauty in experience" as its object. In contrast to this, in normal cases, when the play-instinct does work, we do not experience "Beauty as Idea", but only "the beauty in experience".

The second one is the distinction between "melting beauty" (die auflösende Schönheit) and the "energizing beauty" (die energische Schönheit) (the Aesthetic Education, 119). In this respect, it should be noted "that we must expect from beauty at once a releasing and a tensing effect: a releasing effect in order to keep both the sense-instinct and the form-instinct within proper bounds; a tensing effect, in order to keep both at full strength." (the Aesthetic Education, 111) The releasing effect is the work of melting beauty, whereas the tensing effect is the work of energizing beauty. Melting beauty and tensing beauty are not two unrelated things. Rather, they are two sides of the same coin that is called beauty. They always go hand in hand, as Schiller describes them in the following way: "Ideally speaking, however, these two effects must be reducible to a single effect. Beauty is to release by tensing both natures uniformly, and to tense by releasing both natures uniformly. This already follows from the concept of a reciprocal action, by virtue of which both factors necessarily condition each other and are at the same time conditioned by each other, and the purest product of which is beauty."(the Aesthetic Education, 111)

In this way, the play-instinct is the origin of freedom because freedom is concretely understood as freedom from "compulsion (Zwang)" (the 
Aesthetic Education, 119) as the state of being tense. We could call a man tense "when he is under the compulsion of thought, no less than when he is under the compulsion of feeling. Exclusive domination by either of his two basic instincts is for him a state of constraint and violence [ $\cdots]$." (the Aesthetic Education, 119) The sensuous instinct and the formal instinct compel man to do something and, in this way, make him tense. It is only the play-instinct that could make man free from "the compulsion of thought" as well as from "the compulsion of feeling". From this standpoint, it is clear that "freedom lies only in the co-operation of both his natures. The man one-sidedly dominated by feeling, or the sensuously tensed man, will be released and set free by means of form; the man one-sidedly dominated by law, or the spiritually tensed man, will be released and set free by means of matter." (the Aesthetic Education, 119) It should be noted that the freedom that has its origin in the play-instinct is produced by melting beauty that makes man free from feeling as well as from law. "In order to be adequate to this twofold task, melting beauty will therefore reveal herself under two different guises. First, as tranquil form, she will assuage the violence of life, and pave the way which leads from sensation to thought. Secondly, as living image, she will arm abstract form with sensuous power, lead concept back to intuition, and law back to feeling." (the Aesthetic Education, 119-121) Since the freedom is produced by the melting beauty, it is called "aesthetic freedom" (the Aesthetic Education, 143). Needless to say, what Schiller means by aesthetic freedom is different from the moral freedom in the Kantian sense. Viewed from the aesthetic point of view, moral freedom in the Kantian sense is not freedom, but a compulsion that has its origin in the formal instinct. Man should be also free from 
moral freedom through the aesthetic instinct.

The state in which "the aesthetic freedom" prevails is called "the aesthetic State" (the Aesthetic Education, 215). It is distinguished from "the dynamic State" as the State of the savages as well as from "the ethical State of duties" as the State of the barbarians. In "the dynamic State", "it is as force that one man encounters another, and imposes limits upon his activities" and, in "the ethical State of duties," "man sets himself over against man with all the majesty of the law, and puts a curb upon his desires" (the Aesthetic Education, 215). In the aesthetic State, "none may appear to the other except as form, or confront him except as an object of free play. To bestow freedom by means of freedom is the fundamental law of this kingdom." (the Aesthetic Education, 215)

The aesthetic State is the final stage in the development of mankind. There is no harmony, but only conflict among the individuals in the dynamic State as well as in the ethical State. In contrast to these states, in the aesthetic State, there is no conflict, but harmony among the individuals. In this context, the following three points should be noted: first, that "taste alone brings harmony into society, because it fosters harmony in the individual" (the Aesthetic Education, 215), second, that "only the aesthetic mode of perception makes of him [man] a whole, because both his natures must be in harmony, if he is to achieve it" (the Aesthetic Education, 215), third, that "only the aesthetic mode of communication unites society, because it relates to that which is common to all" (the Aesthetic Education, 215). It is a State of equality in which "no privilege, 
no autocracy of any kind, is tolerated" (the Aesthetic Education, 217). "Here, therefore, in the realm of Aesthetic Semblance, we find that ideal of equality fulfilled [*]." (the Aesthetic Education, 219) Thus, the aesthetic State as a State in which harmony, unification and equality prevail is a State in which man as an individual as well as a genus is happy. "Beauty alone makes the whole happy, and each and every being forgets its limitations while under its spell." (the Aesthetic Education, 217)

2. Schiller's Theory of the Aesthetic Instinct as a Mixture of Dogmatic Metaphysics and the Phenomenology of Aesthetic Instinct

I will now assess Schiller's theory of the aesthetic instinct summarized in section 1. In my view, on the one hand, it contains some difficulties that preclude it from being characterized as the phenomenology of aesthetic instinct, but, on the other hand, it is of great significance for the development of the phenomenology of aesthetic instinct since it is full of phenomenological insights. As will be discussed later, Schiller's theory of the aesthetic instinct that includes these two aspects could be considered to be a mixture of dogmatic metaphysics and the phenomenology of aesthetic instinct. In order to see these two aspects of Schiller's theory of aesthetic instinct, it is important to first point out some of its difficulties.

Schiller's theory of aesthetic instinct has the following methodological difficulty. The method, which Schiller employs to clarify the existence and 
the structure of aesthetic instinct, is the method of abstraction that he calls "the transcendental way". He claims that the method of abstraction enables us to grasp Person and Condition as the "two ultimate concepts" in man. These "two ultimate concepts" are the foundation for the existence of the sensuous instinct and the formal instinct as "two fundamental instincts" in man.

The method of abstraction is problematic, since abstraction could be carried out in different ways according to different research interests. In this context, one may ask why is it the case that the abstraction employed by Schiller leads to two ultimate concepts, not to three or four ultimate concepts? Rather than intuition of the phenomenon itself, I claim, it is prejudices built into the tradition that motivates Schiller to conceive of Person and Condition as the two ultimate concepts in man. For example, Kant's distinction between the epistemological subject and the moral subject, the Cartesian distinction between res congitans and res extensa, the Aristotelian or the scholastic distinction between form and matter, and finally Plato's distinction between Idea and Chora are, in some respects, similar to Schiller's distinction between Person and Condition. As will be discussed in section 3, to develop the phenomenology of aesthetic instinct properly, we have to employ the various kinds of phenomenological method.

The methodological difficulty in Schiller is closely related to another difficulty in Schiller's concept of the aesthetic instinct. As mentioned above, according to Schiller, the aesthetic instinct is not a fundamental concept, but a derivative one, since it is the product of the reciprocal action between the sensuous instinct and the formal instinct as two funda- 
mental instincts. The definition of aesthetic instinct as a derivative instinct is the result of the thesis that Person and Condition are considered to be two ultimate concepts. However, if we do not accept Person and Condition as the two ultimate concepts in man and recognize three ultimate concepts such as Person, Condition and the Aesthetic Play, the fundamental instincts could turn out to be three. In this case, it would be totally possible to designate the aesthetic instinct as the fundamental instinct that underlies Person and Condition.

In this context, it should be noted that J. G. Fichte does not consider the aesthetic instinct to be derived from the other kinds of instinct. He classifies the basic instincts of man into "the knowledge instinct (der Erkenntnistrieb)", "the practical instinct (der praktische Trieb)" and "the aesthetic instinct (der ästhetische Trieb)"4). These three instincts are not reducible to one another and, in this sense, they could be called fundamental rather than derivative. Thus, Fichte does not consider the aesthetic instinct to be a derivative instinct, and he has a different view on the nature of the aesthetic instinct from Schiller.

In my view, Schiller was a little bit hesitant about the issue of whether the aesthetic instinct could be considered to be derivative. In the Aesthetic Educa- tion, there are some passages that seem to support the interpretation of the aesthetic instinct as a fundamental, not derivative one. For example, the following passage from Nineteenth Letter lends support to

4) J. G. Fichte(1974), "Über Geist und Buchstab in der Philosophie (1794)", in: Vermischte Schriften und Aufsätze, Fichtes Werke Bd VIII, ed. by I. H. Fichte(1971), Berlin: Walter de Gruyter, 276 ff. 
this interpretation.

"Each of these two primary instincts, from the time it is developed, strives inevitably, and according to its nature, towards satisfaction; but just because both are necessary, and yet strive towards opposite ends, these two compulsions cancel each other out, and the will maintains perfect freedom between them. It is, then, the will which acts as power (power being the ground of all reality) vis-à-vis both instincts; but neither of these can of itself act as power against the other." (the Aesthetic Education, 135)

Here we have to pay attention to what "the will" in this passage means. In this passage, the will is described as a power that "maintains perfect freedom" between the sensuous instinct and the formal instinct as "two primary instincts." What is, then, the power that "maintains perfect freedom" between the sensuous instinct and the formal instinct in Schiller's aesthetics? It is nothing other than the aesthetic instinct as the play-instinct between the sensuous instinct and the formal instinct. Thus, "the will" in this passage turns out to be the play-instinct as the aesthetic instinct. What is important in this context is the fact that "the will" as the aesthetic instinct "acts as power (power being the ground of all reality) vis-à-vis both instincts" and that "neither of these [the sensuous instinct and the formal instinct] can of itself act as power against the other". Thus, "the will" as the aesthetic instinct turns out to be the power that acts on or through the other two instincts and thereby makes the reciprocal action between them possible. This implies that the aesthetic instinct is not a derivative instinct, but rather it is one of the fundamental instincts that constitute man. 
Even though Schiller's theory of the aesthetic instinct has some difficulties, it is of great significance for the development of the phenomenology of aesthetic instinct, since it is full of important phenomenological insights. Let me give some examples of them.

The first step in developing the phenomenology of aesthetic instinct is to identify the existence of the aesthetic instinct. It should be noted that the concept of the aesthetic instinct may sound somewhat metaphysical and arouse some skepticism with respect to its existence. In this situation, Schiller's theory of the aesthetic instinct could serve as evidence for the existence of the aesthetic instinct, since it could be interpreted as a theory that is based on the concrete experience of the aesthetic instinct that Schiller himself possessed as an artist.

Moreover, even though Schiller's theory of aesthetic instinct is abstract due to the method of abstraction it employs, it is, nevertheless, full of concrete phenomenological analyses of the aesthetic instinct.

One of them is the analysis of the noesis-noema structure of the aesthetic instinct. As is well known, phenomenology considers the noesis-noema correlation to be essential to every kind of consciousness, and the aesthetic instinct is no exception. One of the basic characteristics of the aesthetic instinct is that it has the noesis-noema structure. In fact, in the Aesthetic Education, one can ascertain various kinds of the analysis of the noesis-noema structure of the aesthetic instinct. One of them is the analysis of the object of the aesthetic instinct. As discussed above, Schiller 
maintains that the aesthetic instinct has its own object just as the other kinds of instinct have their own objects. According to him, the aesthetic instinct has Beauty or the living form as its object and, in this respect, it is different not only from the sensuous instinct that has life as its object, but also different from the formal instinct that has form as its object.

Another example of the phenomenological analyses of the aesthetic instinct is the analysis of the mode of the satisfaction of the aesthetic instinct. The original state of instinct is that of starvation as dissatisfaction and instinct strives necessarily towards satisfaction, as Schiller describes with respect to the sensuous instinct and the formal instinct in the Nineteenth Letter: "Each of these two primary instincts, from the time it is developed, strives inevitably, and according to its nature, towards satisfaction []." (the Aesthetic Educa- tion,135) In this respect, the aesthetic instinct is no exception. It also strives towards satisfaction. The process of play as a process of aesthetic experience is nothing other than the process in which the aesthetic instinct strives for satisfaction. In fact, Schiller describes the way to discover Beauty as Idea as a process of satisfying the aesthetic instinct, as a passage from Fifteenth Letter shows: "The beauty we find in actual existence is precisely what the play-instinct we find in actual existence deserves; but with the ideal of Beauty that is set up by Reason, an ideal of the play-instinct, too, is enjoined upon man, which he must keep before his eyes in all his forms of play. We shall not go far wrong when trying to discover man's ideal of beauty if we inquire how he satisfies his play-instinct." (the Aesthetic Education, 107) 
A third example of the phenomenological analyses of the aesthetic instinct is the analysis of the aesthetic world. Every kind of instinct is the origin of the constitution of a specific world. For example, the sensuous instinct is the origin of the constitution of the sensuous world, and the formal instinct is the origin of the constitution of the moral world. In this sense, the aesthetic instinct is no exception, and it is the origin of the constitution of a specific world, namely the aesthetic world. In fact, in Twenty Seventh Letter, employing the concepts of the aesthetic instinct, play and semblance (der Schein), Schiller touches on the issue of the constitution of the aesthetic world as "a third joyous kingdom of play and of semblance" as follows: "In the midst of the fearful kingdom of forces, and in the midst of the sacred kingdom of laws, the aesthetic instinct to form is at work, unnoticed, on the building of a third joyous kingdom of play and of semblance, in which man is relieved from all that might be called constraint, alike in the physical and in the moral sphere." (the Aesthetic Education, 215)

We have observed that Schiller's theory of the aesthetic instinct has difficulties as well as insights for the development of the phenomenology of aesthetic instinct. In my view, Schiller's theory of aesthetic instinct has difficulties for the development of the phenomenology of aesthetic instinct, since it is partly based on dogmatic metaphysics that has its origin in the method of abstraction. In my view, dogmatic metaphysics is one of the aspects of Schiller's theory of the aesthetic instinct. But the same theory has another aspect, namely, that of phenomenological theory, since, as discussed above, it is full of phenomenological insights. If we take into account this aspect, Schiller's theory of the aesthetic instinct could be considered to be a forerunner of the phenomenology of aesthetic instinct. 
Considering these two aspects of Schiller's theory of the aesthetic instinct, we can define it as a mixture of dogmatic metaphysics and the phenomenology of aesthetic instinct.

3. A Brief Sketch of the Phenomenology of Aesthetic Instinct

Through criticizing the dogmatic metaphysical aspects of Schiller's theory of aesthetic instinct, appropriating its phenomenological aspects and examining the various aspects of the aesthetic instinct that are not dealt with by Schiller, I will clarify the aesthetic instinct and thereby develop the phenomenology of aesthetic instinct. In this section, I will briefly sketch the phenomenology of aesthetic instinct.

1) In order to develop the phenomenology of aesthetic instinct properly, we have to first clarify its method. As discussed above, Schiller used the method of abstraction to develop his theory of the aesthetic instinct, and this method leads his theory to a dogmatic metaphysics that is basically arbitrary. The method of abstraction cannot be employed to develop the phenomenology of aesthetic instinct. In order to develop the phenomenology of aesthetic instinct properly, we have to employ various kinds of phenomenological reductions such as the phenomenological-psychological reduction, the transcendental phenomenological-reduction or the eidetic reduction. Concerning this point, it should be noted that the phenomenology of aesthetic instinct 
could take various forms such as eidetic ontology, phenomenological psychology, transcendental phenomenology, etc. In order to develop the various forms of the phenomenology of aesthetic instinct, we need different forms of the phenomenological reduction. For example, we need the eidetic reduction to develop the phenomenology of aesthetic instinct as ontology, and we need the phenomenological psychological reduction to develop the phenomenology of aesthetic instinct as phenomenological psychology. Finally, we need the transcendental phenomenological reduction to develop the phenomenology of instinct as transcendental phenomenology. Moreover, in order to develop the phenomenology of aesthetic instinct systematically, we need the methods of dismantling and constructing (der Ab- und Aufbau). In this context, it should be noted that there are various layers of genetic constitution of aesthetic experience that could be clarified only layer by layer. In order to clarify the various layers of the genetic constitution of the aesthetic experience systematically, employing the method of dismantling, we have to dismantle them step by step, and, after going back to the most fundamental layer of genetic constitution of aesthetic experience by employing the method of the constructing, we have to try to understand how the other layers of genetic constitution of aesthetic experience are developed from that layer. Needless to say, under the circumstances, we have to use the method of the phenomenological interpretation to clarify the various kinds of aesthetic experience that could not be grasped through direct phenomenological reflection carried out from the first-person perspective. 
2) The concept of the aesthetic instinct is not a metaphysical one or a mere theoretical construct that does not have any matter corresponding to it. It is a concept that is founded on the experience of the aesthetic instinct. Here it should be noted that the aesthetic instinct does really exist. There are many evidences that indicate the existence of the aesthetic instinct, and I will enumerate two of them. The first is reflective experience that each of us could have of it. If we reflect on our aesthetic experiences, we feel some motivating force working in us that drives us to have and pursue them. The second is the reports of the artists about their own aesthetic instinct that take various forms such as their diary, letters, autobiography, literature or philosophical works. Schiller's theory of the aesthetic instinct developed in the Aesthetic Education is his report about his experience of the aesthetic instinct in the form of a philosophical work.

3) As discussed above, according to Schiller, the sensuous instinct and the formal instinct are two fundamental instincts, whereas the aesthetic instinct as the play-instinct is a derivative one. Assessing Schiller's concept of the aesthetic instinct, I have shown that, contrary to what Schiller explicitly claims, even in his aesthetics, it is possible to interpret the aesthetic instinct as a fundamental instinct. I do not accept what Schiller claims officially with respect to the basic characteristic of the aesthetic instinct. My argument for the thesis that the aesthetic instinct should be considered to be a fundamental instinct in Schiller's aesthetics is based on the fact that the reciprocal action between the sensuous instinct and the formal instinct is not the work of these two instincts, but the work of the aesthetic instinct itself. This 
implies that the aesthetic instinct should be already there together with the sensuous instinct and the formal instinct, so that it instigates the sensuous instinct and the formal instinct to act reciprocally.

Thus, the aesthetic instinct should be considered to be a fundamental instinct that is not to be reduced to the other fundamental instinct(s). In my view, it is not the method of abstraction employed by Schiller as "the transcendental way", but the phenomenological method that could show that the aesthetic instinct is a fundamental instinct. The phenomenological method in this context means concretely the method of phenomenological interpretation that can be employed for the empirical scientific research such as archaeology, history of art or the depth psychology. Regarding this point, it should be noted that the genetic origin of aesthetic experience is an important topics for archaeology, history of art and depth psychology. If we interpret phenomenologically the various results of the researches in these areas that have relevance for the origin of the aesthetic experience, we could show that the aesthetic instinct is one of man's fundamental instincts.

Furthermore I do not only reject Schiller's theory of aesthetic instinct as being a derivative instinct, but also any aesthetic theories that consider the aesthetic experience to be something reducible to the other instincts. Freud's theory of the art as the result of the sublimation of the sexual instinct is a typical example5). In my view, there are

5) S. Freud(1974), "Eine Kindheitserinnerung des Leonardo Da Vinci (1910)", in: Bildende Kunst und Literatur, Studienausgabe Bd. X, Frankfurt/M.: S. Fischer Verlag, 1969, 87-159. Freud considers the enormoursly strong knowledge-instinct of Leonardo Da Vinci to be a sublimation of "the sexual instinct (der Sexualtrieb)" (104). For him, the sexual instinct 
many aesthetic experiences that might be interpreted as the result of sublimating the sexual instinct, but it is not the case that every kind of the aesthetic experience can be considered to be the result of the sublimation of the sexual instinct. In this context, it should be noted that the aesthetic instinct might begin to work later than the other instincts, but this does not imply that it is a derivative instinct, whereas these other instincts are fundamental ones.

4) The aesthetic instinct is the beginning of any aesthetic experience such as the aesthetic creation or the aesthetic appreciation. It is the beginning of any aesthetic creation in the sense that an artist who begins creating an artistic work is driven by the aesthetic instinct. It is also the beginning of any aesthetic appreciation in the sense that a person who begins to appreciate a work of art is driven by the aesthetic instinct. In this context, it should be noted that the encounter with a work of art is surely a necessary condition, but not a sufficient condition for the beginning of the act of appreciating an artwork. The working of the aesthetic instinct is needed for beginning the act of appreciating a work of art on the part of the spectator. In order to understand this fact, one might compare the following two cases with each other. In one case, a person encounters a work of art, but he does not appreciate it as a work of art, but only as an ordinary object of everyday life. In another case, another person encounters the same artwork, but he does appreciate it

is the fundamental instinct and the other instincts are derived ones that have their origin in the sexual instinct. In this respect, the aesthetic instinct is no exeception. It is also a derivative instinct that has its origin in the sublimation of the sexual instinct as the fundamental instinct. 
as a work of art. Thus, in the first case, there is not yet an aesthetic apperception of the artwork on the part of the person, whereas, in the second case, there is an aesthetic apperception of the artwork on the part of the person. What is the difference between these two cases? In my view, in the first case, the aesthetic instinct is not yet awakened in the person who encounters the work of art, whereas, in the second case, it is.

After the beginning of the first act of the aesthetic experience, the aesthetic experience does not disappear as long as the aesthetic instinct is still present. This implies that the aesthetic instinct is the driving force that keeps the aesthetic experience active. Many aestheticians consider play to be the essence of the aesthetic experience. Schiller is a typical example for them, and he considers the play of the sensuous instinct and the formal instinct to be the essence of aesthetic experience. As is well known, before Schiller, Kant considered the play between the imagination and the understanding to be the essence of aesthetic experience6). I claim that the whole process of the aesthetic experience as a process of playing is the work of aesthetic instinct. So long as the aesthetic instinct continues to work, the aesthetic experience as a process of aesthetic playing continues and at the moment when the aesthetic instinct stops, the aesthetic experience as a process of aesthetic playing also stops. Needless to say, the intensity of the aesthetic experience is dependent on the intensity of the aesthetic instinct. The more intense the aesthetic instinct, the

6) I. Kant(1974), Kritik der Urteilskraft, Hamburg: Felix Meiner, 55 ff. 
more intense the aesthetic experience.

5) Aesthetic instinct is the origin of aesthetic feeling. The aesthetic feeling is an important topic for aesthetics after the subjective turn in the aesthetics in the seventeenth century. For example, in Kritik der Urteilskraft, Kant deals with the issue of the pleasant feeling that is related to art work ${ }^{7}$. According to him, one gets a pleasant feeling, when one encounters a work of art and thereby experiences the play between the imagination and the understanding. Kant describes the pleasant feeling as if it were the last fact that could not be explained anymore. In my view, however, Kant should have traced the origin of the aesthetic feeling and should have identified the aesthetic instinct as the origin of that feeling. In order to understand the connection between the aesthetic instincts and the aesthetic feeling, we have to pay attention to the fact that the aesthetic instinct like all the other kinds of instinct strives towards the satisfaction and that the satisfaction of the aesthetic instinct results in the aesthetic feeling.

Like Kant, Schiller considers the aesthetic feeling to be the central concept in his aesthetics. In fact, "the purely aesthetic feeling (das reine ästhetische Gefuhl)" (the Aesthetic Education, 198) or "the aesthetic mood or attunement (die ästhetische Stimmung)" (the Aesthetic Education, 147) is an important topic of Letters 20-268). Contrary to

7) Ibid, p. 44 .

8) E. M. Wilkinson and L. A. Willoughby translate "das reine ästhetische Gefuhl" into "the purely aesthetic sense" (the Aesthetic Education, 199), but I translate it into "the purely aesthetic feeing". They translate "Stimmung" mainly into "the mode", but I translate it 
Kant, however, Schiller does not consider the aesthetic feeling to be the final fact that could not be traced further. Rather, he deals with the issue of aesthetic feeling in close connection with the issue of the aesthetic instinct. He considers the aesthetic instinct to be the final origin of the aesthetic feeling. In this context, it is important to see that the aesthetic feeling is closely related to the aesthetic freedom that has its origin in the aesthetic instinct 9 ).

6) The aesthetic instinct sheds a new light on the issue of whether aesthetic experience is disinterested. One of the traditional positions concerning this issue is that aesthetic experience is not interested ${ }^{10}$ ). According to this position, aesthetic experience is not interested in matters of everyday life such as those related to class, sex, race, society, politics, economics, etc. But this does not imply that the aesthetic experience has nothing to do with interest at all, since it has a peculiar interest that might be called the aesthetic interest. The aesthetic interest is different from the various kinds of interest of everyday life. If only the interest of everyday life deserves to be called interest, then one can say that the aesthetic experience does not have any interests. In my view, the claim that the aesthetic experience has nothing to do with interest is based on the assumption that only the

into "mood or attunement". Sometimes they also translate "Stimmung" into "mood" (the Aesthetic Education, 153).

9) With respect to the close connection between the aesthetic feeling and the aesthetic freedom, Schiller writes as follows: "This lofty equanimity and freedom of the spirit, combined with power and vogour, is the mood in which a genuine work of art should release us, and there is no more certain touchstone of true aesthetic excellence." (the Aesthetic Education, 153)

10) A typical example for this position is I. Kant, Kritik der Urteilskraft, $40 \mathrm{ff}$. 
interest of everyday life deserves to be called interest. However, this assumption is problematic, and we should admit that the aesthetic interest is a kind of interest. It should be noted that the genetic origin of the aesthetic interest is the aesthetic instinct. So long as the aesthetic instinct is awakened, the aesthetic interest is alive. The stronger the aesthetic instinct works, the stronger the aesthetic interest is.

7) In many cases, the aesthetic instinct does not work by itself, but it works together with the other instincts. For example, an artist could begin a work of art which is to serve a religious purpose. In this case, not only the aesthetic instinct, but also the religious instinct is the driving force that motivates him to produce the work of art. Or the same person could produce a work of art to earn a living. In this case, not only the aesthetic instinct but also what Schiller calls the sensuous instinct is the driving force that motivates the person to produce a work of art. It is also possible for the same person to produce a work of art to serve a religious purpose and, at the same time, to earn a living. In this case, the aesthetic instinct, the religious instinct and the sensuous instinct are the driving forces that motivate the person to produce the work of art. Thus, the aesthetic instinct could work together with the other instincts. What happens to the aesthetic experience that is motivated by the aesthetic instinct, when the aesthetic instinct works together with the other instincts? There could be cases in which the other instinct(s) could oppress the working of the aesthetic instinct, and they could have a detrimental effect on the aesthetic experience. In an extreme case, the aesthetic experience could be turned into a non-aesthetic experience, and the art 
could change into a mere technique. However, there are also cases in which the other instinct(s) could intensify the working of the aesthetic instinct, and they could function for the aesthetic instinct in a positive way. There are endlessly many cases in which the religious zeal of an artist is the motivating force for the creation of a masterpiece.

8) The aesthetic instinct could shed a new light on the structure of the aesthetic attitude. The aesthetic attitude is an important topic for the contemporary aesthetics. In the phenomenological tradition, we have a general agreement that there is an aesthetic attitude11). In the analytic philosophy, however, it has been a hot issue if there is an aesthetic attitude ${ }^{12)}$. With respect to this issue, there are conflicting positions: On the one hand, some scholars claim that there is really an aesthetic attitude13) and, on the other hand, some scholars claim that there is no aesthetic attitude, as the title of the article "The Myth of the Aesthetic Attitude"14) indicates. In my view, there really is an aes-

11) Husserl talks about the aesthetic attitude, for example, in Erste Philosophie II (Husserliana VIII), p. 101. M. Dufrenne attempts a detailed analysis of the aesthetic attitude in M. Dufrenne(1973), The Phenomenology of Aesthetic Experience, trans. by E. S. Casey, Evanston, Il: Northwestern University Press, pp. 426-439.

12) D. E. W. Fenner gives an overview of the history of the discussion about the issue of the aesthetic attitude in D. E. W. Fenner(1996), The Aesthetic Attitude, Atlantic Highlands, N.J.: Humanities Press.

13) For example, J. Stolnitz(1969), Aesthetics and Philosophy of Art Criticism, Boston: Houghton Mifflin; J. Stolniz(1961), “Some Questions Concerning Aesthetic Perception”, Philosophy and Phenomenological Research 22; V. Tomas(1959), "Aesthetic Vision", The Philsophical Review 68; F. Sibley(1959), "Aesthetics and the Looks of Things", Journal of Philosophy 56.

14) G. Dickie(1964), "The Myth of the Aesthetic Attitude", American Philosopbical Quarterly 
thetic attitude, as we have the term "the aesthetic attitude" in ordinary language. Of course, it would be unfair to claim that those scholars who deny that there is aesthetic attitude have not contributed anything. In my view, their contribution lies in having shown that the traditional theory of the aesthetic attitude is unsatisfactory. In this respect, I would like to note that, even in the phenomenological tradition, no satisfactory theory of the aesthetic attitude has been developed. This is due to the fact that the traditional phenomenological aesthetics has not attempted to clarify the genetic development of the aesthetic attitude thoroughly. In my view, the aesthetic instinct is the final genetic foundation of the aesthetic attitude. And the best way to prove that the aesthetic attitude is not a myth is to show how the aesthetic attitude is formed on the basis of the aesthetic instinct, which is, at the same time, the best way to clarify the structure of the aesthetic attitude. In this respect, I would like to point out that, like all the other instincts, the aesthetic instinct does not disappear from the field of consciousness after its first appearance, but it appears again and again and, in this way, makes it possible that the aesthetic habit is formed on the part of the person as the bearer of the aesthetic instinct. The aesthetic habit formed through the repeated function of the aesthetic instinct is an important component of the aesthetic attitude.

9) The aesthetic instinct could also shed a new light on the structure of the aesthetic world. As discussed above, Schiller touches upon the 
issue of the aesthetic world. In this context, in Twenty Sixth Letter, dealing with the problem of the aesthetic semblance, he talks about "the world of semblance" (the Aesthetic Education, 197) that could be called the aesthetic world. This concept of the aesthetic world is an important topic for contemporary aesthetics in general, for example, for aesthetics of the phenomenological school15), for aesthetics of the analytic school16) and perhaps for the other schools of aesthetics as well17). Unfortunately, there is no agreement about the concept of the aesthetic world between these schools. The concept of the aesthetic world is used ambiguously. Sometimes it refers to the world of artwork that is incorporated in the artwork18), and sometimes it is identified with the social institution ${ }^{19}$ ). The different concepts of the aesthetic world have to be separated from one another and clarified in detail. In my view, however, the concepts of the aesthetic world could not be clarified thoroughly, if we do not take into account the aesthetic instinct. The reason for this is that the aesthetic instinct is the very origin of the constitution of all the aesthetic and, in this respect, the aesthetic world is no exception.

15) M. Dufrenne(1973), attempts a detailed analysis of the aesthetic world in chapter 5 of The Phenomenology of Aesthetic Experience, trans. by E. S. Casey, Evanston, Il: Northwestern University Press, pp. 147-198. Chapter 5 has the title: "Aesthetic Object and World".

16) A. Danto(1964), "The Artworld", The Journal of Philosophy 61/9; H. S. Becker(1982), Art Worlds, Berkeley: University of California Press; G. Dickie(1974), Art and the Aesthetic, Ithaca, N.Y.: Cornell University Press; G. Dickie(1984), The Art Circle, New York: Haven.

17) P. Bourdieu(1996), The Rules of Art: Genesis and Structure of the Literary Field, trans. by S. Emanuel, Cambridge: Polity Press.

18) M. Dufrenne(1973), The Phenomenology of Aesthetic Experience, trans. by E. S. Casey, Evanston, Il: Northwestern University Press, pp. 147-198.

19) G. Dickie(1974), Art and the Aesthetic, Ithaca, N.Y.: Cornell University Press. 


\section{Concluding Remarks}

Taking Schiller's theory of the aesthetic instinct in the Aesthetic Educationas the guiding point, I have tried to provide a brief sketch of the phenomenology of aesthetic instinct. I will close the discussion of the phenomenology of aesthetic instinct by making two remarks.

1) It is my task in the future to clarify in more detail the various issues of the phenomenology of aesthetic instinct sketched in section 3 and thereby to develop the phenomenology of aesthetic instinct systematically. I hope that the phenomenology of aesthetic instinct will be able to elucidate the various issues of aesthetics and consequently open a new horizon for contemporary aesthetics.

2) There are still many issues concerning the phenomenology of aesthetic instinct that were not addressed in section 3 at all. For example, there is a close relationship between the aesthetic instinct and the aesthetic rationality, and the aesthetic instinct could shed new light on the issue of aesthetic rationality. It will be my future task to deal with all the other important issues concerning the aesthetic instinct that were not mentioned in section 3 . 


\section{References}

Becker, H. S.(1982), Art Worlds, Berkeley: University of California Press.

Bourdieu, P.(1996), The Rules of Art: Genesis and Structure of the Literary Field, trans. by S. Emanuel, Cambridge: Polity Press.

Danto, A.(1964), "The Artworld", The Journal of Philosophy 61/9.

Dickie, G.(1974), Art and the Aesthetic, Ithaca, N.Y.: Cornell University Press.

(1984), The Art Circle, New York: Haven.

(1964), "The Myth of the Aesthetic Attitude", American Philosophical Quarterly I/1.

(1966), "Attitude and Object: Aldrich on the Aesthetic", in: The Journal of Aesthetics and Art Criticism 25/1.

Dufrenne, M.(1973), The Phenomenology of Aesthetic Experience, trans. by E. S. Casey, Evanston, Il: Northwestern University Press.

Fenner, D. E. W.(1996), The Aesthetic Attitude, Atlantic Highlands, N.J.: Humanities Press.

Fichte, J. G.(1794), "Über Geist und Buchstab in der Philosophie”, in: Vermischte Schriften und Aufsätze, Fichtes Werke Bd VIII, ed. by I. H. Fichte(1971), Berlin: Walter de Gruyter.

Freud, S.(1910), "Eine Kindheitserinnerung des Leonardo Da Vinci", in: Bildende

Kunst und Literatur, Studienausgabe Bd. X, Frankfurt/M.: S. Fischer Verlag (1969).

Husserl, E.(1956), Erste Philosophie II, Den Haag: Martinus Nijhoff.

Kant, I.(1974), Kritik der Urteilskraft, Hamburg: Felix Meiner.

Schiller, F.(1982), On the Aestbtetic Education of Man in a Series of Letter, English and German Facing, trans. by E. M. Wilkinson and L. A. Willoughby, New York: Oxford University Press.

Sibley, F.(1959), "Aesthetics and the Looks of Things", Journal of Philosophy 56.

Stolnitz, J.(1969), Aesthetics and Philosophy of Art Criticism, Boston: Houghton Mifflin. (1961), "Some Questions Concerning Aesthetic Perception", Philosophy and 
454 인문논총 제68집 (2012)

Phenomenological Research 22.

Tomas, V.(1959), “Aesthetic Vision”, The Philsophical Review 68.

원고 접수일: 2012년 11월 14일

심사 완료일: 2012년 11월 23일

게재 확정일: 2012년 12월 4일 


\section{요 약 문}

\section{F. Schiller(1759-1805)와의 대화를 통해 전개한 예술본능의 현상학}

이 남 인

쉴러는 『인간의 미적교육에 관하여』에서 유희본능(유희충동) 개념을 자신의 미학의 핵심 개념으로 도입한다. 이 경우 유희본능은 예술본능을 의미한다. 그런데 쉴러의 유희본능은 긍정적인 측면과 부정적인 측면을 가지고 있다. 그것은 한편으로 미학의 주요 주제들을 새롭게 조망할 수 있도록 해주는 미학의 핵심 개념으로 탈바꿈할 가능성을 가지고 있으며 다른 한편으로 나름의 문제점들도 가지고 있다. 이 논문의 목표는 쉴러 의 유희본능 개념이 가지고 있는 이러한 두 가지 측면을 평가하면서 예 술본능이 무엇인지 해명하고 그를 통해 예술본능의 현상학의 근본구상 을 전개하는 데 있다. 이러한 목표를 위해 우리는 우선 1절에서 쉴러의 예술본능의 개념을 정리하고 2절에서 그것의 긍정적인 측면과 부정적인 측면을 해명한 후 3절에서 예술본능 개념의 몇몇 주요한 측면들을 현상 학적으로 해명하면서 예술본능의 현상학의 근본 구상을 전개할 것이다. 